\title{
Euripides' Iphigenia in Tauris and Homer
}

\section{John Davidson}

Euripides' Iphigenia in Tauris (henceforth IT) is one of a number of plays surviving from antiquity, most of which are by Euripides, which today present problems of genre definition. It is technically a "tragedy" yet to us it seems more like an adventure romance. This is because, while disaster does threaten in the course of the exciting action, in the event no character comes to harm and there is a happy ending. We have to remember, however, that since the time of Euripides and Sophocles, the meaning of the word "tragedy" has undergone something of a transformation.

The ancient concept is clearly articulated by Aristotle in the Poetics and presumably based by him on the tradition of serious dramas performed in a serious manner at festivals in honour of the god Dionysus. What is essential for a tragedy in the ancient Greek sense, as he states, is a plot containing metabasis or change of fortune. This may be from good to bad, but it may also be from bad to good. This latter pattern conflicts with the modern notion of tragedy, though interestingly this modern notion is already present in Aristotle's discussion.

In chapter 13 of the Poetics he outlines what he considers to be the best type of plot for the most effective tragedy, and he famously finds the model in Sophocles' King Oedipus. The pattern identified includes a change of fortune from good to bad, and at this point Aristotle refers to Euripides. He says that Euripides is wrongly criticised for employing this pattern in most of his plays since it is superior in terms of tragedy. And he goes on to say indeed that for this reason Euripides is "the most tragic" of the poets, despite his other areas of "mismanagement" which he is also very happy to specify in other parts of the Poetics.

Aristotle's statement that Euripides is "the most tragic" of the poets has often been taken out of context. In fact, all that Aristotle says is that Euripides is "the most tragic" because of what was apparently the highest proportion of his plays which used plots showing the change from good to bad fortune. This in itself, of course, has become something of an irony, since the vagaries of chance have resulted in a situation in which nearly $30 \%$ of the surviving tragedies of certain Euripidean authorship, including the 
$I T$, show the bad to good fortune pattern, even if some of these have significant dark colouring. ${ }^{1}$ By contrast, of Sophocles' seven surviving tragedies, the Philoctetes is the only clear example of the bad to good fortune pattern, as is the Eumenides in the case of Aeschylus.

Be that as it may, in the IT we have a most dramatic play which contains, among other things, an example of what Aristotle identifies in chapter 14 of the Poetics as the type of situation which is most conducive to arousing the twin tragic emotions of pity and fear. This seems to fly in the face of what he has just said in chapter 13 , because the most tragic type of situation turns out to be that in which, as we find in the $I T$, someone is about to kill a relative without knowing the identity of the person, but at the last moment discovers the identity and so does not kill the person after all. $^{2}$

In the $I T$, Iphigenia has been saved from the sacrificial knife at Aulis by the goddess Artemis and spirited away to become priestess of a cult in the land of the Taurians which sacrifices all foreigners (including Greeks) who come to its shores. Her brother Orestes has arrived with his companion Pylades under instructions from the god Apollo to steal the sacred statue of Artemis and take it back to Greece. Only then can he be freed from the persecution of a splinter group of Furies who have not accepted his acquittal on the charge of killing his mother in revenge for his father's murder at her hands. Arriving in the barbarian land, the two young men have been captured, and Iphigenia is about to have him sacrificed when she learns his identity (as he learns hers) and so saves him, then concocting a plan for them all to escape with the statue. She thus incurs the murderous wrath of the barbarian king Thoas who is, however, mollified by an appearance of the goddess Athene ex machina. Athene also gives instructions for the establishment of cults at Halae and Brauron in Attica.

1 This percentage increases to $35 \%$ if, against most probability, we count the "happy ending" of Iphigenia at Aulis as Euripidean.

2 Many modern commentators, however, are at pains to explain away this apparent anomaly. Thus, for example, Stephen Halliwell, Aristotle's Poetics (London: Duckworth, 1986), 226, argues: “... not only does the tragedy of averted catastrophe conform [...] to Aristotle's major conditions, but it also in a sense contains within itself, and goes beyond, the ideal tragedy of ch. 13." 
Given the elements of intrigue, danger, near-death and exciting escape, it is not surprising that the IT has generated a number of adaptations in modern times, the best known of which are probably Gluck's Iphigénie en Tauride (1779), his fifth opera for the French stage, with libretto by Nicolas-François Guillard, and Goethe's Iphigenie auf Tauris first published in 1787, with verse replacing the original prose version of $1779 .^{3}$ There were, of course, other versions before this. Goethe himself, for example, seems to have taken the innovation of having Thoas make a marriage proposal to Iphigenie from the 1697 play Oreste et Pylade by the French dramatist François Joseph Lagrange-Chancel. Then too, Gluck was anticipated by Tommaso Traetta's Ifigenia in Tauride (early 1760s). ${ }^{4}$ The insecurity of genre associated with Euripides' play also partly created the platform for Franz Grillparzer's Lustspiel entitled Weh dem, der lügt! (1838), itself reflecting his uneasy artistic response to Goethe.

The present paper, however, is not concerned with the Reception of Euripides' play, fascinating though this is. Rather, it looks back from Euripides to Homer in an attempt to isolate key aspects of artistic contact between the poet of the Iliad and Odyssey and the fifth-century tragedian, developing the recent discussion of this topic by Klaus Lange. ${ }^{6}$ Lange observes that it is to the Odyssey in particular that Euripides turns, ${ }^{7}$ and this is just what one might expect, given the greater variety of settings, situations and incidents encountered there, not to mention models for the motifs of return, revenge and recognition. ${ }^{8}$

${ }^{3}$ For a survey of critical reactions to Goethe's play, see Irmgard Wagner, Critical Approaches to Goethe's Classical Dramas (Columbia: Camden House, 1995), 590.

${ }^{4}$ Gluck's great rival Niccolo Piccinni produced an Ifigenia in Tauride, two years after Gluck's version, also at the Paris Opéra, as a counterblast to Gluck's operatic reforms, but it was a failure.

5 See Hansgerd Delbrück, "Grillparzers Lustspiel Weh dem, der lügt! und die Iphigenie-Dramen Goethes und des Euripides," Deutsche Vierteljahrsschrift für Literaturwissenschaft und Geistesgeschichte 67 (1993): 140-72.

6 Klaus Lange, Euripides und Homer (Hermes Einzelschriften 86), (Stuttgart: Steiner, 2002), 102-15.

${ }^{7}$ Lange (n. 6 above), 102.

8 I am leaving out of consideration any reference to the lost Epic Cycle poem Nostoi (Returns). The summary found in the Chrestomathia of Proclus makes it 
In general, the shadow of Homer hovers over all subsequent Greek literature as successive generations of authors have sought to establish themselves in relation to the master. As far as tragedy is concerned, Aeschylus, Sophocles and Euripides all made distinctive contributions. In the case of Aeschylus, we have on record his remark reported by Athenaeus (8.347e) that his plays were merely slices from Homer's great banquets, and it has been argued that he is the one who is perhaps consistently closest to Homeric diction. ${ }^{9}$ It is Sophocles, however, who in the ancient testimonia is generally considered to hold the place of honour in this company. Although in some ways the least "Homeric" of the three, Euripides nevertheless engaged innovatively with the Iliad or the Odyssey in a number of his tragedies. ${ }^{10}$

With regard to the $I T$ specifically, Lange is being rather modest when he writes in his conclusion: "Die Iphigenie im Taurerland gehört nicht $\mathrm{zu}$ den herausragenden Beispielen euripideischer Homerimitatio" ("the IT does not belong to the outstanding examples of Euripidean Homer imitation"). However, in his very next sentence he goes on to say: "Dennoch schimmert Homerisches fast beständig durch" "11 "nevertheless, Homericism shows through almost continually"). I would like to build on this platform.

In constructing his drama of intrigue, Euripides appears to have taken Odysseus as at least the partial model for his Orestes. This quasi-identification is admittedly not as palpable as that exploited in the Electra. In that play, Euripides makes clear his specific allusion to the basic Odyssean pattern of a return incognito for the purpose of revenge and repatriation, through details such as the

clear that this epic dealt with Orestes' revenge at least, and Euripides may well have drawn on it. However, very little of the work survives and, in any case, the Odyssey always enjoyed a much higher status. We might compare the situation by which Sophocles, though reportedly being much influenced by other poems of the Epic Cycle such as the Little Iliad, clearly drew significantly on the Iliad for his Ajax and on the Odyssey for his Philoctetes, although the storyline in both cases derived from the Epic Cycle.

9 Alexander Sideras, Aeschylus Homericus (Göttingen: Vandenhoeck \& Ruprecht, 1971), 12.

${ }^{10}$ Lange (n. 6 above), for example, also discusses Electra, Helen, Orestes and Cyclops in this connection.

${ }^{11}$ Lange (n. 6 above), 114. 
scar as means of recognition. ${ }^{12}$ There is, moreover, the fact that in the Odyssey the return and revenge of none other than Orestes is repeatedly invoked as an encouraging paradigm. The IT, on the other hand, is not a story of return home and revenge. However, it still seems that many of its plot features are consciously designed to recall other plot features and also the hero of the Odyssey.

In very general terms, everything that happens in the play is a consequence of the Trojan War which, at least with regard to the poetic tradition, points back ultimately to the Iliad as the starting point, but the play's time setting is the post-war era which belongs to the period of the Odyssey. Furthermore, although Orestes' arrival in the land of the Taurians is not, as we have noted, in itself a nostos, it represents a point on the way to a final homecoming, and involves one of a number of trials and tribulations in the course of a period of extensive wandering.

As in other plays, Orestes is accompanied on his journey by Pylades, a situation which recalls the travelling companionship of the young men Telemachus and Peisistratus in the Odyssey when they set out from Pylos on a mission of discovery to Sparta. Then too, he makes a maritime landing in a barbarian land, as Odysseus himself does more famously when he goes ashore in the land of the Cyclopes. In the introduction to his commentary on the play, Martin Cropp ${ }^{13}$ well documents the main "deficiencies" of the Taurians, including their lack of commerce with other people, their violation of the laws of hospitality which leads even to the murder and mutilation of strangers, their rudimentary technology, lack of religious insight, and gullibility. And he notes that these characteristics contribute to a picture not only of non-Greekness as projected by Greek writers on to barbarian peoples, but also of mythical subhumanity of the type illustrated by Homer's Cyclopes.

Odysseus faces a particular ogre adversary in the form of Polyphemus. In the case of Orestes, the ogre figure with whom he has to contend is split in two. There is, first of all, the barbarian king Thoas who is the prime mover as far as the sacrifice of

12 See, for example, T.A. Tarkow, "The Scar of Orestes: Observations on a Euripidean Innovation," Rheinisches Museum für Philologie 124 (1981): 143-55, and B. Goff, "The Sign of the Fall: the Scars of Orestes and Odysseus," Classical Antiquity 10 (1991): 259-67.

${ }^{13}$ M.J. Cropp (ed.), Euripides Iphigenia in Tauris (Warminster: Aris and Phillips, 2000), 47-50. 
strangers is concerned. Orestes, however, does not have a face-toface confrontation with the king, who in fact only becomes a direct source of menace in the latter stages of the play. The more immediate threat to Orestes is posed by the king's agent, so to speak, that is Iphigenia herself. She it is who is charged with overseeing the human sacrifice of strangers and thus putting the monstrous barbarian practices into operation. Iphigenia is a female, of course, and so in another sense she replicates the dangerous and exotic female adversary whom Odysseus encounters in Circe. On the other hand, especially given the context of barbarous practices, she fulfils the Polyphemus role, and this can be seen especially in the sequence where, like the Cyclops, she interrogates her captive.

A vital ingredient of this sequence is that, in its initial stages, Orestes' name must not be revealed. In the Cyclops incident in the Odyssey, Odysseus does not reveal his true name in response to Polyphemus' questioning, but brands himself as "Outis" or "nobody," a stratagem which pays handsome dividends later for Odysseus himself in the storyline and for Homer in terms of plot manipulation. There is a telling parallel in the IT sequence.

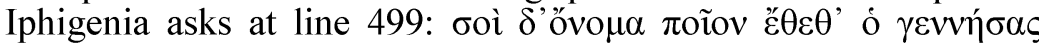
$\pi \alpha \tau \eta$ p; ("and what sort of name did the father who sired you give

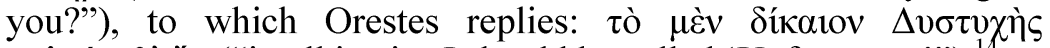
$\kappa \alpha \lambda$ ó $\mu \varepsilon \theta$ ' őv ("in all justice I should be called 'Unfortunate"').

There is, of course, a different reason for the suppression of the name and the substitution of a generalising abstraction-Euripides needs to preserve as long as possible the ignorance of their true identities on the part of Iphigenia and Orestes, so as to heighten the dramatic tension, until its release through the revelation involving the contents of the letter which Iphigenia proposes to send back to Greece with Pylades. However, there seems little doubt as to where the basic model comes from.

The interrogation sequence in the $I T$, then, clearly on one level evokes the Cyclops incident. There is, however, another factor which again links the scene intimately with the Odyssey. As I have discussed in an earlier paper, ${ }^{15}$ a number of surviving fifth-century dramas contain a scene in which someone who has missed the

\footnotetext{
${ }^{14}$ Cf. Lange (n. 6 above), 109.

15 J. Davidson, "What about the Greeks who went to Troy?: Three Tragic Contexts and Homer," Classica et Mediaevalia 57 (2006): 5-17.
} 
Trojan War, so to speak, seeks information from someone else who has had first-hand experience of it. Thus the Euripidean Helen quizzes Teucer in the Helen, and Philoctetes does the same to Neoptolemus in the Philoctetes, while there is a brief parody of the sequence in the Cyclops, as Odysseus is questioned about the postwar fate of Helen. And so it is that in the $I T$ we find Iphigenia, a little later in the interrogation sequence, pumping the Greek stranger for news about various figures who played key roles of different kinds in the war.

These question and answer scenes no doubt involve an element of cross fertilisation, but the ultimate model is clearly the incident in Odyssey book 3 in which Telemachus cross-examines Nestor about events at Troy. With regard to the specific question about Odysseus, which Iphigenia poses to Orestes, Lange points also to Menelaus' report to Telemachus of what Proteus said to him about Odysseus. Lange comments on Orestes" "surprising" knowledge of Odysseus' problems and adds: "Orest hat gewissermaßen eine 'metamythische' Quelle, eben die Odyssee" ("Orestes has, so to speak, a 'metamythic' source, precisely the Odyssey"). Thus the IT interrogation sequence combines the questioning by the barbarian of the Greek interloper with the enquiry about key figures associated with the Trojan War.

In the broadest terms too the recognition motif found in the IT as well as in many other plays derives ultimately from the Odyssey. More specifically, within the recognition pattern, we find in the IT, as in some other plays, the situation in which characters exalting in the joy of newly awakened recognition are warned of the surrounding dangers and the need to behave more circumspectly, in order to achieve some surreptitious goal. ${ }^{17}$

The paedagogus fulfils the role of warner in Sophocles' Electra, while the chorus is the equivalent player in the Choephori. Pylades does the job in the IT, though his warning is amusingly brushed aside in a clear send-up of the tradition. Once again, the model is to be found in the Odyssey, this time in book 21, where Odysseus himself brusquely interrupts his own joyful embraces with Eumaeus and Philoetius. In broad plot terms again too, we find the

\footnotetext{
${ }^{16}$ Lange (n. 6 above), 113.

17 See J. Davidson, "Beware of the Danger: A Homeric Motif in Fifth Century Drama," Classica et Mediaevalia 51 (2000): 17-28.
} 
necessity for a ruse to escape the barbarian, as seen also in the Odyssey Cyclops incident.

Many other points can be added. Detailed consideration of Homeric verbal echoes in the $I T$ is not possible here, but mention may just be made of a few cases. For example, in line 89 in the prologue Orestes states that Apollo has told him to get hold of the

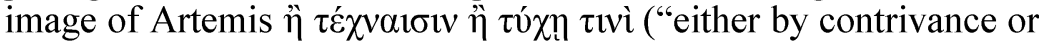
a lucky chance"). This wording is similar to what the same character says in lines 36-37 of the prologue of Sophocles' Electra about the god's instruction to him to exact revenge not by force of arms but by "trickery" ( $\delta$ ó $\lambda \circ 1 \sigma \imath)$. In both cases we are dealing with a formula which derives from the Homeric formula about the options for return and revenge. For example, the goddess Athene, disguised as Mentes, urges Telemachus, in the event that his father does prove to be dead, to consider the murder of the suitors $\eta \dot{\varepsilon}$ $\delta$ ó $\lambda \omega$ ү̀ $\alpha \mu \varphi \alpha \delta$ óv ("either by trickery or openly"-Odyssey 1.296). The most relevant of these examples, however, are the disguised Odysseus' accounts, first to Eumaeus and then to Penelope, of a report that Odysseus had gone to consult the oracle at Dodona

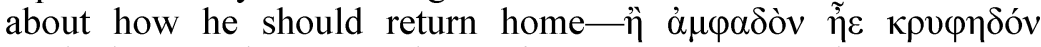
("whether openly or secretly," Odyssey 14.329-30 and 19.298-99).

Then again, at lines $175-76$ of the $I T$, Iphigenia laments in her lyric dialogue with the incoming chorus how she is $\tau \eta \lambda$ ó $\varepsilon . .$. $\pi \alpha \tau \rho i ́ \delta$ os ("far from her native land"), a version of the oftenrepeated Homeric formula $\tau \eta \lambda{ }^{\prime} \theta r$ á́ $\tau \rho \eta \varsigma$. And Lange ${ }^{18}$ rightly draws attention to the motif parallel between the rock cleft by the sea where, according to the herdsman messenger's report to Iphigenia, one of his comrades had caught sight of Orestes and Pylades (initially presuming them to be divinities), and the cave of the nymphs in Odyssey book 13. He then goes on to note an even more telling connection. In the description of the bay of Phorcys where the cave of the nymphs is said by Homer to be located, we find the verbal combination ... $\dot{\alpha} \pi \mathrm{\rho} \rho \rho \tilde{\omega} \gamma \varepsilon \varsigma \ldots \kappa \tilde{v} \mu \alpha \ldots$. . Odyssey 13. 97-100). In the IT, the herdsman messenger's locus est opening

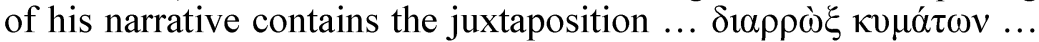
(IT line 262).

The rocky cleft in the $I T$ where Orestes and Pylades take refuge is full of other Homeric associations as well. As a cave or quasi-

${ }^{18}$ Lange (n. 6 above), 104-05. 
cave in a barbarian land it brushes against the Cyclops' cave. But it also serves as a kind of staging post on the way to the accomplishment of a mission, as Electra's hut does for Orestes in that Euripidean play, which in turn goes back to Eumaeus' hut in the Odyssey. We can add further the motif of knowledge of a feature of the family home as proof of identity. Thus Orestes is able to convince Iphigenia that he really is her brother by recalling the spear of Pelops which is stored in the "girls' apartments" in the palace at Argos (IT lines 822-26). ${ }^{19}$ This arrangement as such is similar to that in the Odyssey by which Odysseus' bow is stored in a special room, but the more relevant parallel is the hero's use, in Odyssey book 23, of his detailed knowledge about their marriage bed to convince Penelope that her husband has indeed returned. ${ }^{20}$

Another clear link between the IT and the Odyssey is the remarkable incident, described to King Thoas by the messenger at the end of the play, in which the escaping Greek ship is driven back to the shore, as Polyphemus' first boulder also threatens the survival of Odysseus in his escaping ship in Odyssey book 9. There is also the fact that Orestes has come to steal a sacred object just as Odysseus entered Troy to steal the Palladion, though admittedly this is not specifically referred to in the Odyssey. One can even see in the figure of Iphigenia both a reflection of Odysseus trapped on Calypso's island, given her own entrapment far from home, and also of Penelope weeping for Odysseus, as she laments the supposed death of Orestes on account of her incorrect dream interpretation. This dream, in which the entire palace collapses apart from a single column which then assumes human features and takes on a human voice, finds its model in Penelope's dream in Odyssey book 19 where the eagle also takes on a human voice. In connection with Penelope too, mention may be made of her famous weaving which may well at least have contributed to a further detail in the $I T$ recognition sequence by which Orestes reminds Iphigenia of her own girlhood weaving of pictures from the story of Atreus, Thyestes, the golden lamb and the disruption of the sun's normal course (IT lines 811-17).

\footnotetext{
${ }^{19}$ See the note on lines $823-25$ by Cropp (n. 13 above).

${ }^{20}$ Relevant too is Odysseus' detailed knowledge of the trees in the garden which he demonstrates to his father Laertes in the recognition sequence in Odyssey book 24. See also J. Dingel, "Der 24. Gesang der Odyssee und die Elektra des Euripides," Rheinisches Museum für Philologie 112 (1969): 103-09.
} 
It is time to draw some conclusions. By way of preface, it needs to be stressed that the argument of this paper is certainly not that Euripides' $I T$ is to be seen as simply a kind of rerun of the Odyssey. We are dealing, in fact, with an extremely rich tapestry. There is no doubt for a start that, as well as the wanderings of Odysseus, the voyage of the Argonauts is also directly evoked. Thus, in terms of motifs, Orestes can also be seen as a Jason figure enjoying the favour of the local princess in order to escape from the barbarian king after accomplishing a dangerous mission. Aspects of the plot too might be said to follow the kinds of ritual patterns which are to be replicated in the cult practices to be established at Halae and Brauron. There are, moreover, numerous similarities with other tragedies such as Euripides' Helen, and especially those associated with the Orestes story, in particular the two surviving Electra plays. For all that, however, there do seem to be clear grounds for concluding that the Homeric intertext is at least an extremely important component of this Euripidean masterpiece.

The question, though, is why Euripides would allude so frequently to the Homeric corpus, and especially to the Odyssey. This is actually a very complex question with regard to any of his plays, and it is particularly intriguing in this case. In the Electra, for example, we can more easily point to ironic effects such as that by which, whereas Odysseus got his recognition scar in a boar hunt, Orestes' has been gained in a childhood accident chasing a pet fawn in the backyard - and that too in an overall context where the "Odyssean" avenger is directing his murderous designs against his own mother. The situation with regard to the IT is considerably more elusive.

At the most basic level, it can be asserted with some confidence that Euripides, like many other authors, is simply seeking, and finding in the Odyssey, a convenient model for an adventure story involving travel to a barbarian land, danger, recognition of identity, escape and so on. These motifs already exist in the Homeric epic and, in using them, Euripides is clearly positioning himself in the Greek literary tradition. Within these broad motifs too there are specific details such as the danger warning theme, the theme of request for information on the part of someone cut off from a certain event, and the theme of recognition prompts which the Odyssey also conveniently supplies. Is it possible, though, to go beyond this? 
There are certainly hints of the kind of ironic contrast which is more palpable in other plays. Thus Lange ${ }^{21}$ points to the fact that the seagoing Odysseus is pursued constantly by the anger of Poseidon, whereas Orestes is only momentarily threatened by the god through the particular wave which drives his ship back to the shore and jeopardises his escape. There is also the point that while Athene is never too far away from Odysseus, even appearing to him at certain critical moments of his adventures, Apollo is not much help at all to Orestes, despite sending him on his mission. Moreover, it is actually Athene who arrives at the very end to save the situation. In the Odyssey too, the hero has to fight against some especially nasty barbarian enemies, such as the Cyclops Polyphemus and the Laestrygonians, in order to extricate himself and his men from dangerous situations and effect an escape. Orestes, on the other hand, while fighting against "barbarians," is in fact fighting against unarmed herdsmen, or temple-servants who believe that they are observers of a religious purification ritual.

There is also the point that in the $I T$, as indeed in other Euripidean plays, a higher degree of complexity of characterisation has been introduced. Thus an Orestes, still suffering from Furyinduced madness, is surely to be seen in contrast to the more onedimensional Odysseus figure. Odysseus too is presented as having an absolute right to reclaim his heritage and take vengeance on the suitors in his own home, whereas Orestes, already ethically compromised by the matricide, has come as an intruder to the land of the Taurians to steal a sacred object, in a state of hesitation and uncertainty about the entire mission. The Iphigenia figure too is a complex combination of a barbarian enemy, a potentially threatening female religious figure akin to Theonoe in the Helen, and a lamenting, quasi-Penelope figure, while demonstrating aspects of Odysseus himself in her deep feelings about "exile" and the longing to return home. The greater complexity of Iphigenia, of course, has provided a platform for writers in modern times, such as Goethe, to go even further in this regard.

Finally, it is in the Homeric epics that the seeds of tragedy are to be found. Thus, in the Iliad, Achilles' mênis leads to the death of his best friend, and in the Odyssey, the hero's bad fortune is

${ }^{21}$ Lange (n. 6 above), 103. 
reversed, while the good fortune of the suitors is destroyed. ${ }^{22}$ The IT of Euripides fits the Odyssean rather than the Iliadic tragic mould, with the plot movement following a predominantly bad to good fortune trajectory. Its frequent, consciously designed allusions to the Odyssey align Euripides as a tragedian with one strand of the Greek literary tradition along with one model of heroism, but also mark his innovative departures from epic paradigms. He has laid a platform for further major developments in the ongoing development of European literature.

\section{Addendum}

The IT (whose date of production is generally thought to have been around 414 or $413 \mathrm{BC}$ ) was not, of course, the last time that Euripides dealt with the story of Iphigenia. At the very end of his life he returned to the subject, and his Iphigenia at Aulis (IA) was produced at Athens posthumously in conjunction with Bacchae and the lost Alcmeon in Corinth, probably in $405 \mathrm{BC}$. There is considerable disagreement among modern scholars as to how much of the transmitted text of the $I A$ was actually written by Euripides and how much by a later hand or hands, whether for the original production or for revivals in the next century. One recent editor indeed credits a very considerable proportion of the text to a supposed fourth-century reviser. ${ }^{23}$

Even critics with a less "slash and burn" approach for the most part regard the transmitted ending of the play (lines 1532-1629) as a later addition. This ending features a messenger speech relating how Iphigenia, on the point of being sacrificed, was spirited away and a deer substituted as the victim, an incident designed to align the play mythically with the earlier $I T$ which has just such a divine intervention as its very premise. If the play as conceived by Euripides (and his literary executor) for the original production ended with Iphigenia's death, then it would have to be counted as a

\footnotetext{
22 Aristotle contends in chapter 13 of the Poetics that such a plot of "double structure" is, despite what some may say, inferior in terms of tragic effectiveness to the plot of "single outcome."

${ }^{23}$ David Kovacs (ed. and trans.), Euripides Bacchae, Iphigenia at Aulis, Rhesus (Cambridge, Mass. and London: Harvard University Press, 2002).
} 
"tragedy" in the modern sense. The ending as we have it would give it a "bad to good fortune" plot pattern.

The shadow of Homer still hovers over this late play, although the predominant text in this case is the Iliad rather than the Odyssey. Homer does not know about or at least chooses to ignore the story of Iphigenia's sacrifice, and does not even record her as one of the three daughters of Agamemnon mentioned at Iliad 9.145 and 287. However, one of these has the similar name Iphianassa. Agamemnon himself, Menelaus and Achilles, leading figures in the Iliad, all appear in the $I A$, but they are characterised by Euripides in such a way as to set up a pointed comparison with their namesakes in the Homeric text. Menelaus, for example, becomes much more manipulative, while Agamemnon's Iliadic qualities of vanity, tendency to vacillate, and acute awareness of public opinion are all heightened. Since the play is set in the period before the actual Trojan War has begun, there is no scope for the military prowess of the brothers to be featured.

It is on Achilles, however, that the most significant contrast with the Homeric model is concentrated. As one critic writes of him: "His Homeric features are reduced to narrative devices brought up by characters in need of a saviour, but they fail to materialize. The character who emblematically stands as a symbol of heroism in the Iliad, the single most authoritative poem of the Greek world, is now reduced to a figure unable to defend Iphigenia and his own heroic identity." 25 This is despite the fact that whereas the Iliadic Achilles implores his mother, the sea goddess Thetis, for help, his Euripidean counterpart says in lines 973-74 to Clytemnestra (at least in the text as we have it): $\alpha \lambda \lambda$ ' $\dot{\eta} \sigma u ́ \chi \alpha \zeta \varepsilon$. $\theta \varepsilon$ co $\varsigma$

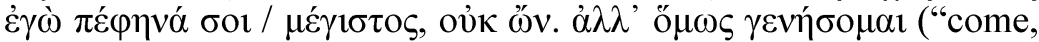
calm yourself. I have appeared to you as a very great god, although not being one. Yet I will become one"). ${ }^{26}$

The contrast between the Homeric and Euripidean visions is nowhere better illustrated than in the parodos or entry song of the

\footnotetext{
${ }^{24}$ On this play in general, see Gudrun Mellert-Hoffmann, Untersuchungen zur "Iphigenie in Aulis" des Euripides (Heidelberg: Carl Winter Universitätsverlag, 1969).

25 Pantelis Michelakis, Euripides: Iphigenia at Aulis (London: Duckworth, 2006), 40.

${ }^{26}$ See Martin Hose, Euripides: Der Dichter der Leidenschaften (München: Verlag C.H. Beck, 2008), 228.
} 
chorus which in this play consists of young married women who have come as sightseers to view the Greek fleet about which their husbands have told them. They give an idealised account of various Greek heroes whom they have seen engaged in various activities, the climax being their sight of Achilles displaying the swiftness of foot which had become legendary in the tradition through the descriptive formula applied to him by Homer in the Iliad. Moreover, he is testing his speed against a chariot driven by Eumelus, one of the competitors in the chariot race instituted by Achilles as part of the funeral games for Patroclus in Iliad book 23. As another critic puts it: "The epic tone of the ode creates a strong counterpressure for a return to past myth and a more glorious world than that of the stasis-ridden army and its leadership presented up to this point in the play.",27 This is followed by a miniCatalogue of Ships in the spirit of the epic version in Iliad book 2 (though Euripidean authorship of this section is in doubt). The second stasimon or choral ode of the play too offers a vision of the situation at Troy as the Greeks will encounter it, the Iliadic situation re-imagined as the future.

It can clearly be seen, then, that in the $I A$, just as in the $I T$, Euripides was using the tragic genre as a platform through which to critique and re-evaluate epic assumptions and values by evoking them in the context of a world that he saw and presented as radically different. It would be left to writers in modern times to continue and refine this process.

27 Helene P. Foley, Ritual Irony: Poetry and Sacrifice in Euripides (Ithaca and London: Cornell University Press, 1985), 79-80. 